University for Business and Technology in Kosovo

UBT Knowledge Center

UBT International Conference

2018 UBT International Conference

Oct 27th, $10: 45$ AM - 12:15 PM

\title{
Examining student engagement in the learning process
}

Marigona Sefedini

University for Business and Technology, marigona.olluri@ubt-uni.net

Follow this and additional works at: https://knowledgecenter.ubt-uni.net/conference

Part of the Education Commons

\section{Recommended Citation}

Sefedini, Marigona, "Examining student engagement in the learning process" (2018). UBT International Conference. 126.

https://knowledgecenter.ubt-uni.net/conference/2018/all-events/126

This Event is brought to you for free and open access by the Publication and Journals at UBT Knowledge Center. It has been accepted for inclusion in UBT International Conference by an authorized administrator of UBT Knowledge Center. For more information, please contact knowledge.center@ubt-uni.net. 


\section{Table of Contents}
Abstract
Chapter I: Introduction......................................................................................................................6

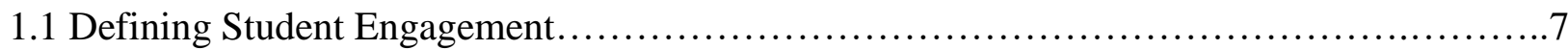

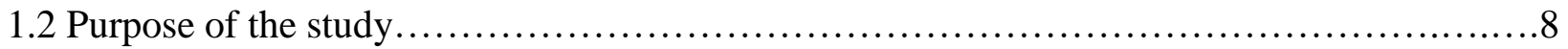

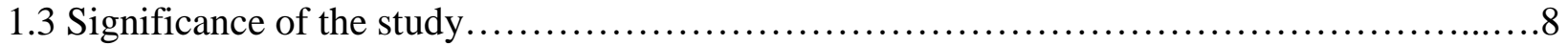

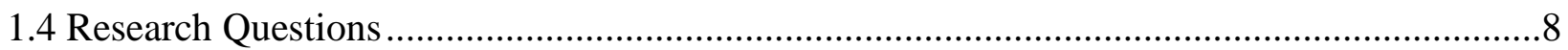

Chapter II: Literature Review................................................................................................................9

Chapter III: Methodology ........................................................................................................................10

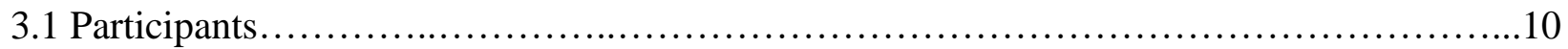

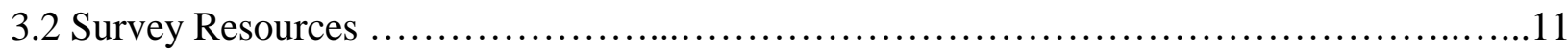

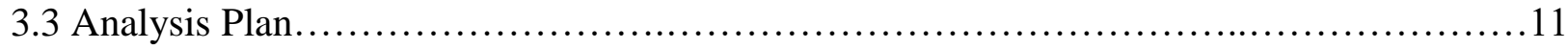

Chapter IV: Results and Discussion.............................................................................................12

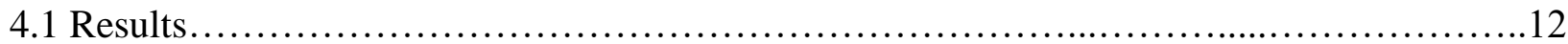

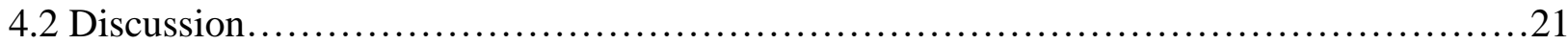

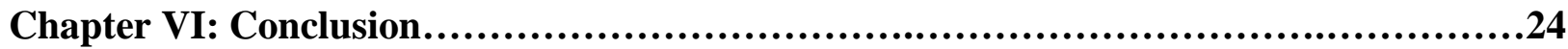

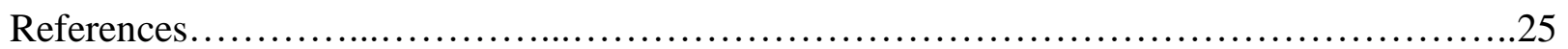

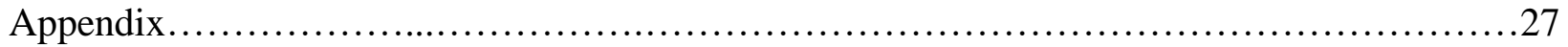




\begin{abstract}
Becoming skilled readers, writers, speakers, listeners, and thinkers requires ample opportunity for practice, authentic reasons for communicating, and effective instructional support (Marzano, 1992). To achieve competence in literacy, students must be motivated to engage with literacy tasks and to improve their proficiency as readers and writers. Instruction and practice then provide the coaching and feedback necessary to gain competence. Increased competence inspires continued motivation to engage (Irvin, 2007). This paper researches three levels on student engagement and how those levels can be enhanced. It first discovers behavioral engagement from students to reveal if behaviors have an influence in the learning process, then it identifies cognitive engagement of students about knowledge and acquirements students have for engagement and lastly, it aims to find the emotional engagement through students' perceptions and opinions.
\end{abstract}




\section{CHAPTER I}

\section{INTRODUCTION}

Studies have shown that when students are engaged in learning, the process in general increases but when students show disinterests and no will, learning fails (Ballantine, 1997; McLeod, 2008; Ogbu, 1982; Ream \& Rumberger, 2008; Almasi \& Gambrell, 1997, as cited in Paratore, n.d.). Research has been conducted to discover the importance of students, primarily by examining engagement through perceptions students have toward learning, to understanding acquirements and knowledge they possess about student engagement and lastly, by focusing on students' behavior during the lecture, from which will be easier to find out the level of learning that takes place when students are engaged and the type of activities that encourage engagement (Arum and Roksa, 2011; Kuh et al, 2005; Ramaley, 2002). Kuh, Laird and Umbach (2004) convey that students who are actively engaged in the classroom gain more from college than those who are not involved in the learning process. Additionally, students' engagement is formed on the belief that learning improves when students are inquisitive, interested or inspired and when they show no interest, the process of learning decreases (Bernstein, 1997; Brantlinger, 1993; Heath, 1983; Britton, 1987, as cited in Goswami, n.d). In search for a better understanding, I have researched students of universities of different fields, their perception about student engagement. Through questionnaires with different questions about engagement process to students of different ages, the study has provided rich data to further examine the concept of student engagement. Furthermore, literature has helped me a lot to understand the basis of this concept, and collecting data from questionnaires helped me discover students' opinions and knowledge about it. 


\subsection{DEFINING STUDENT ENGAGEMENT}

Student engagement is defined in various ways and, at times, used interchangeably with terms such as school bonding, school attachment, school engagement and school connectedness (Libbey, 2004; Kaser \& Short, 1997; Pascarella, 1985, as cited in Smart, n.d.). Engagement in the classroom is a very important feature that brings essential educational outcomes to students. Separated in different levels, student engagement helps students and teacher identify needs and lacks for achieving in learning. Friedrick, Blumenfeld and Paris (2004) recognized three definitions of engagement. The first of these is behavioral engagement and refers to students' actual participation in school and learning. This includes observable behaviors such as positive conduct, persistence in learning and involvement in school life. Behavioral engagement is seen as crucial to academic achievement and the prevention of dropping out of school (Aitken \& Neer, 1993; Allen, Long, O'Mara \& Judd, 2008). The second definition is emotional engagement and refers to students' emotional responses to teachers, peers, learning and school emotional engagement is seen as creating connections with school and influencing willingness to do the work. Finally, cognitive engagement stresses investment in learning, seeking challenge and going beyond self-regulation strategies to control and monitor learning process (Erickson, 1987; Balas, 2000; Bean \& Peterson, 1998, as cited in Anderson, n.d.). 


\subsection{PURPOSE OF THE STUDY}

The intent of the study is to examine student engagement in the learning process. The study will be based on questionnaires answered by 30 students of the University of Prishtina and UBT College. There was not any specific purpose or goal behind the contribution of students of these universities, in the survey. In my experience as a student, I have noticed various ways student can get engaged in the learning process. Consequently, I have been exploring and understanding the techniques students approach in the classroom and what are their perceptions toward it.

\subsection{SIGNIFIANCE OF THE STUDY}

Students' methods in engaging in the classroom are different. Professors imply these methods to get students' orientation and attention in learning. By testing students on behavioral and cognitive engagement in the classroom, the study will be able to assess and to find activities that orientate students in this process. Applying these variants will lead to efficient and successful results on examining student engagement. The outcome of this study may contribute to research on student engagement and provide a better understanding of methods that push students get inspired in learning.

\subsection{RESEARCH QUESTIONS}

The research questions were focused on:

- Examining student engagement in the learning process

- Identifying methods that inspire students to learn

- Finding students perceptions toward engaging in the classroom 


\section{CHAPTER II}

\section{LITERATURE REVIEW}

This research paper serves to highlight the measurement of student engagement and its points through which it can be examined. For decades, educators and educational researchers have been interested in the effects of students' attitudes about the learning process and their experiences in university (Friedrick \& McColskey, 2012; Windham, 2005; Willms, 2003, as cited in Oblinger, n.d.). Friedricks, Klem and Connell (2004) discuss different concepts to reveal what they think is important to study when it comes to attitudes and experiences. For instance, Marks (2000) and Friesen (2008) conceptualized engagement as a "psychological process specifically, the attention, interest, and investment and effort students expend in the work of learning." Connell and colleagues exemplified two forms of engagement: ongoing engagement, which includes student behavior, feeling and thinking skills during the learning process, 2) and reaction to challenge, which refers to students' coping strategies for covering problems and failures in the university (Connell \& Wellborn, 1994; Skinner, Zimmer, Gembeck \& Connell, 1996). This separation is not intended to imply a definitive separation, but to give a better understanding student engagement. Furthermore, engagement is connected with dropping out (Irvin, Meitzer \& Dukes, 2007; Hargreaves, 2004). It is true that students that are less engaged have less achievements, then it is possible that they are more likely to drop out. In general, students' engagement impacts to students in several areas and the measurement of it differs from each point we analyze (Libbey, 2004). 


\section{CHAPTER III}

\section{Methodology}

The purpose of this study was to examine student engagement in the learning process at the university. A quantitative form of research was used to gather information from undergraduate students. A quantitative research is concerned with discovering facts about social phenomena, it assumes a fixed and measurable reality. The data is collected through measuring things and analyzed through numerical comparisons and statistical inferences (McLeod, 2008). With the intention to acquire more information the questionnaire involved questions on different areas of engagement in the classroom, such as the cognitive engagement, behavioral and emotional area. Through these areas, the study will reveal the students' knowledge and information about engagement, their opinions, feelings and wills about it and also their behaviors during the lessons.

\subsection{Participants}

The survey was distributed by paper-based questionnaires to 30 respondents. The respondents were from the University of Prishtina and UBT College. As I mentioned above, there is no specific reason for the contribution of students of such universities. Respondents were undergraduate students of different fields, such as linguistics, architecture, engineering and economics. The questionnaire was distributed in the Albanian language for the main reason that such students may not be familiar to the English Language. 


\subsection{Survey Resources}

The instrument used to collect data on this survey was a questionnaire. It contained 9 questions consisting of 3 pages of A4 format. The form of the questionnaire was close-ended, divided in 3 part of questions. The first part deals with the emotional engagement, the second with the behavioral area and the last part is mainly focused on the cognitive engagement level. Beside these parts, the introductory part of the questionnaire is a short summary of what the students will be expected to answer in the following. The questionnaire took approximately 10-15 minutes.

\subsection{Data Analysis}

The first research question was in examining student engagement in the learning process what are their feelings and opinions toward the engaging procedure. The second research question dealt with students' acquirements and insights about students' involvement in the classroom and its benefits. And the last research question was to examine the students' behaviors during the learning process, how they participate and contribute in the classroom. 


\section{CHAPTER IV}

\section{RESULTS AND DISCUSSION}

\subsection{Results}

The respondents who answered the survey were from different years of study $-11.5 \%$ were first year students, $30.8 \%$ were second year students. $38.5 \%$ attended the classes of the third year and $19.2 \%$ were fourth year students. The contributors of the survey were students of architecture, business, linguistics and engineering. In the very first question, asking whether students feel happy or unhappy when having to follow lectures, the majority of the responders confirmed that they are happy and encouraged when they go to university.

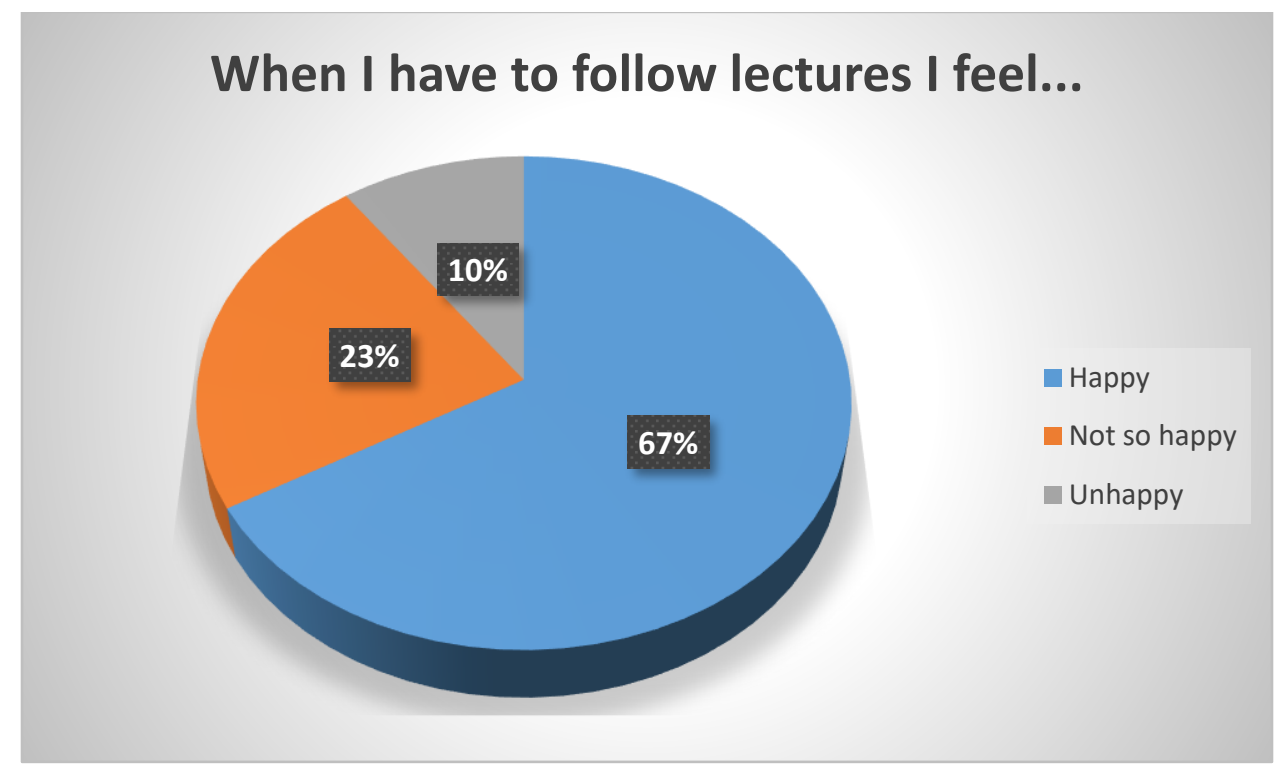

Fig. 1 - Students feeling toward following lectures

The vast majority of students deciphered in $80 \%$ admit that they follow lectures. According to the data gathered from the survey, most of the students feel happy to go to university. Among students who gave a positive answer, students feel happy when lectures consist of tutorials too. In this way they do not get bored and uncomfortable during the learning process. 


\section{Is important to have good relationship with professors and colleagues?}

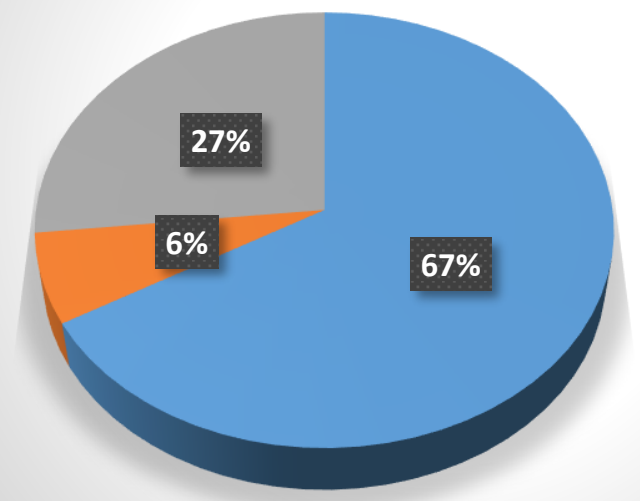

Always

Sometimes

- Often

Never

Fig. 2 - Students behaviors in relationship with professors and colleagues

In the next question, a greater number of students accept that having a good relationship with professors and colleagues plays a huge role in the advancement of a student as a learner. Ratings about advantages of having good behaviors with professors and colleagues show that students who show respect to their tutors and peers are better in learning and are more encouraged to learn. The majority of students admit that this is necessary and they consider it as an important feature. 


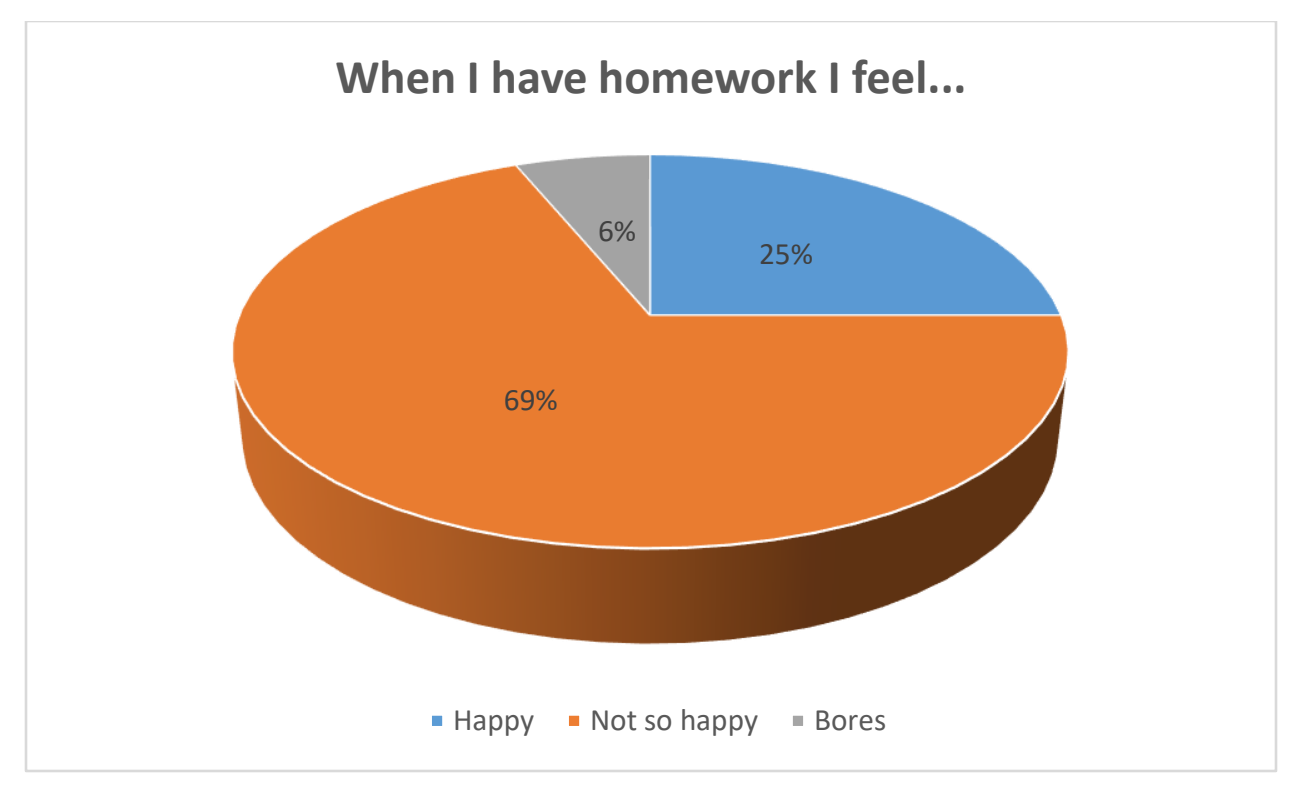

Fig. 3 - Students' considerations about having homework

Homework are often considered to be not so preferable by students (Mayes, Cutri, Rogers \& Montreo, 2006). Even though, students seemed to be interested in learning, they showed an objection toward homework. Among students' preoccupations when being involved in the learning process is that they consider homework a waste of time and when having homework a majority of them admits that they remain passive. They are more interested in activities and practices during the lesson, rather than homework. In the question asking whether they feel happy, not so happy or bored with homework assignments, one-fourth of students confirm that they are encouraged to do homework and the rest are against it. 


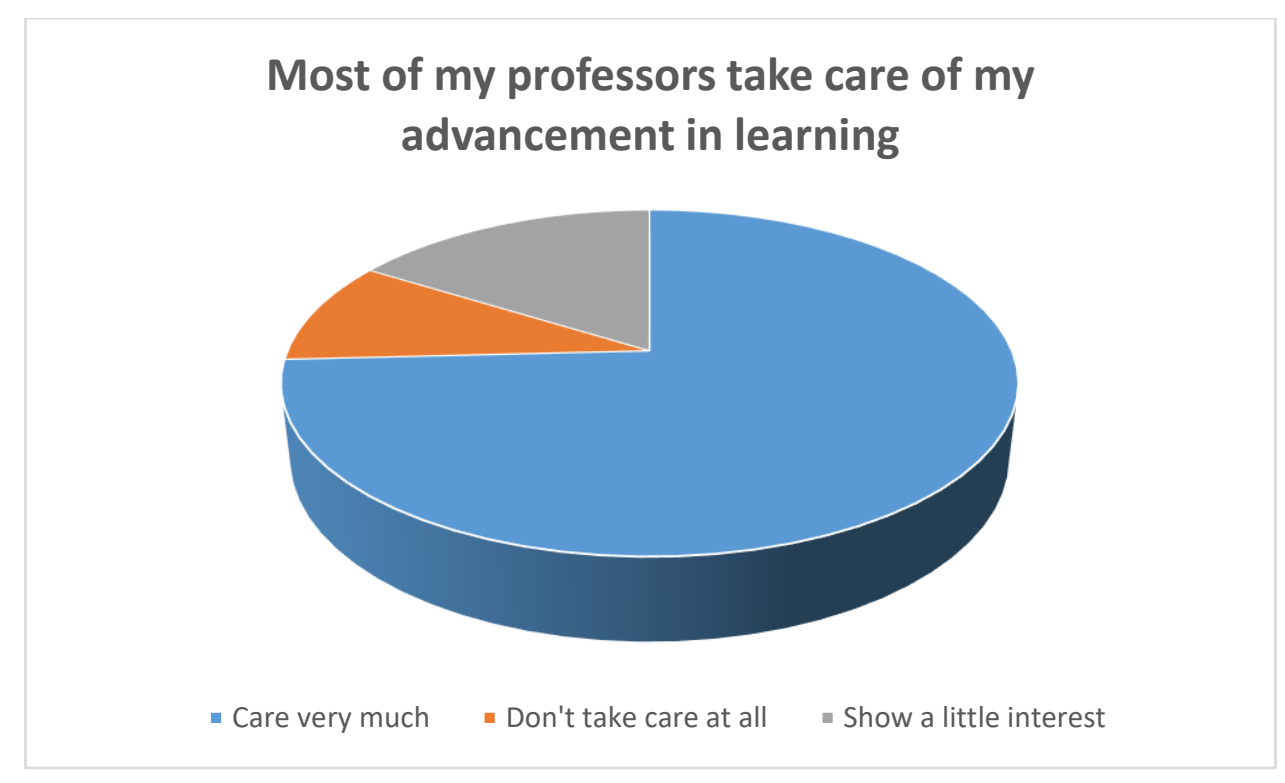

Fig. 4 -Students' perceptions about professors' behavior toward their learning development

Another issue that influences the performance and encouragement of students in the learning process is also professors' behavior and interest in students' advancement. Sometimes professors' creativity and good will to teach influences in students' concern in learning. Considering the importance of professors' attention in the learning development, a question was compiled to determine students' perception and experience to this subject matter. More than half of the participants reveal that their professors take great care of them and the rest of the students convey that their professors do not show an interest toward them. 


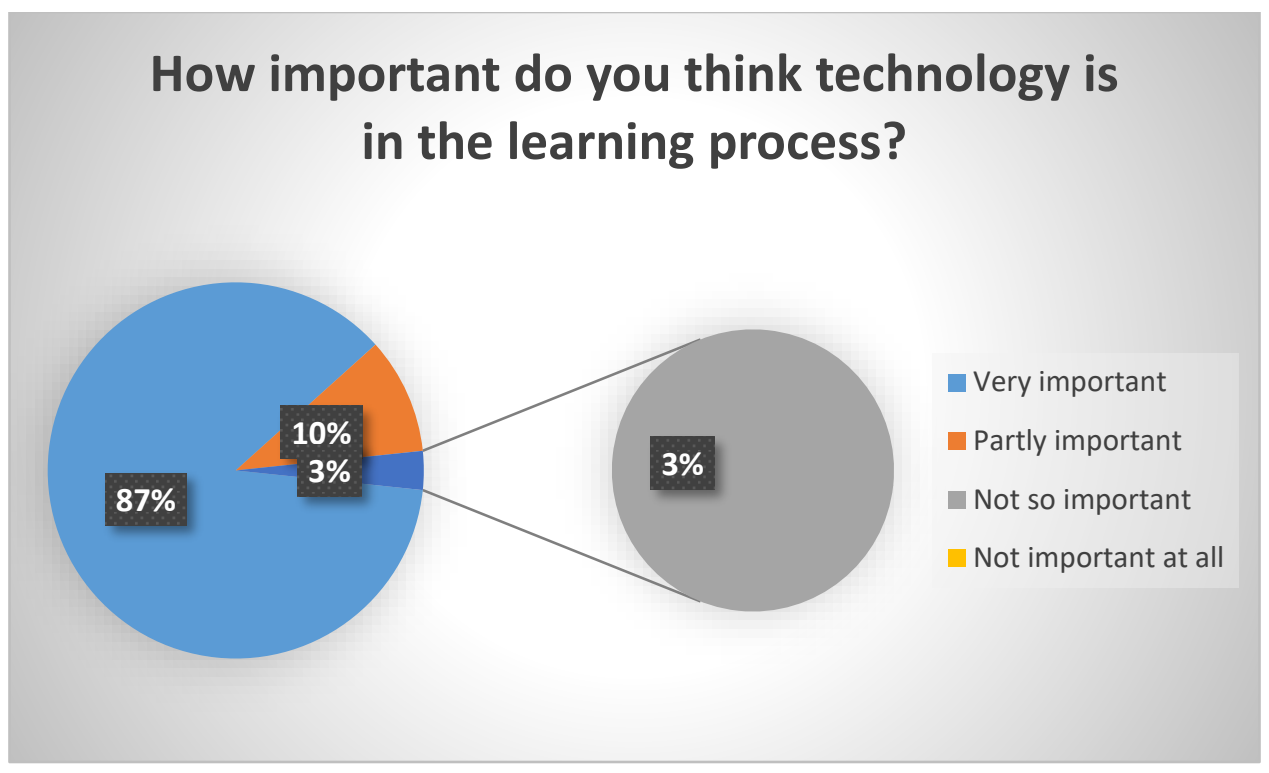

Fig. 5 - How important students consider involvement of technology in the learning process

Student engagement is important to universities and educators, and the usage of technology is one strategy used by universities. Modeling engagement with technology is an easier way through which professors can get students' attention faster than with other methods. According to the data gathered from the survey, students admit that technology is important in making them active during a lesson and defining their goals better. 


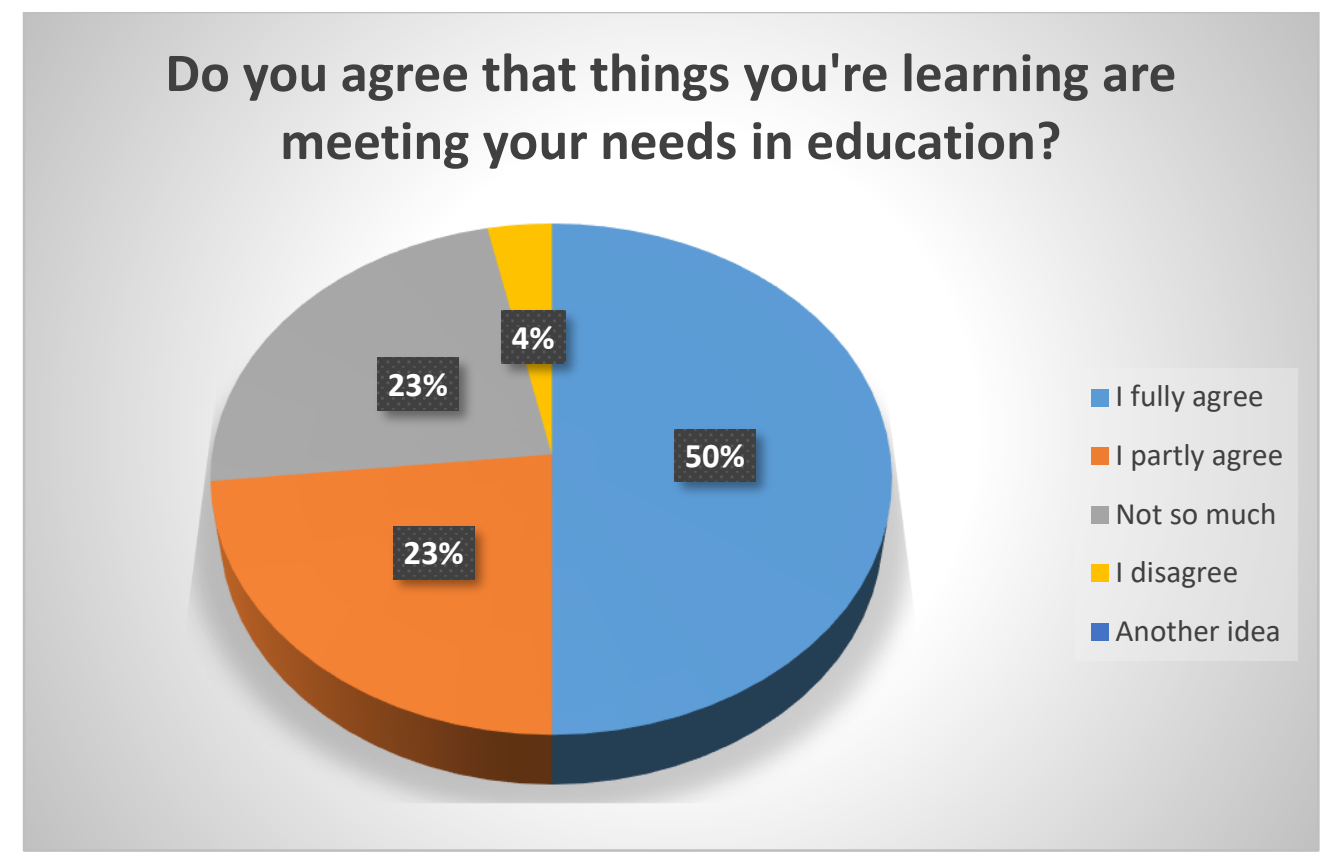

Fig. 6-Students opinion about advancement from the things they are learning

In order to get more information from students and their engagement in the learning process, the sixth question was made to reveal if they are satisfied with what they are learning and if that is fulfilling their needs in education. Providing options that students could select in addition with the replenishment of their requirements, half of the students fully agreed that they are learning what they need to have, whereas a huge part of them partly agreed and also a big percentage of them conveyed that things they are learning are not so helpful to supplement the knowledge they see as necessary. However, only $4 \%$ of the students disagreed. 


\section{Have you ever thought about skipping classes?}

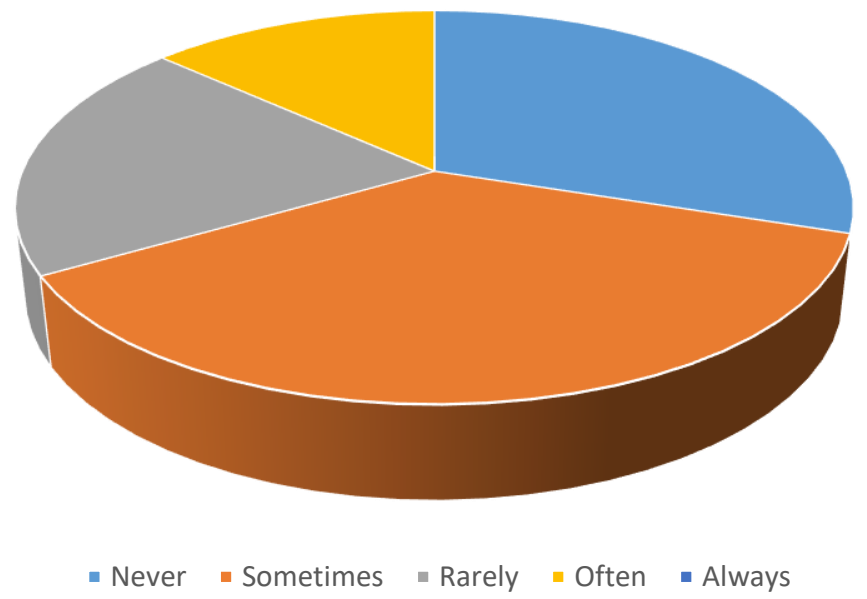

Fig. 7 - Students opinions about skipping classes

The seventh question revealed thoughts and perceptions students have about skipping classes. Even though, following lectures is important in achieving high quality of learning some students tried or experienced skipping classes for certain reasons. This is another issue that influences in the learning progress. Responses of participants show that they never thought for skipping classes, however, another percentage quite similar to this one reveals that they have thought and tried skipping classes sometimes. 


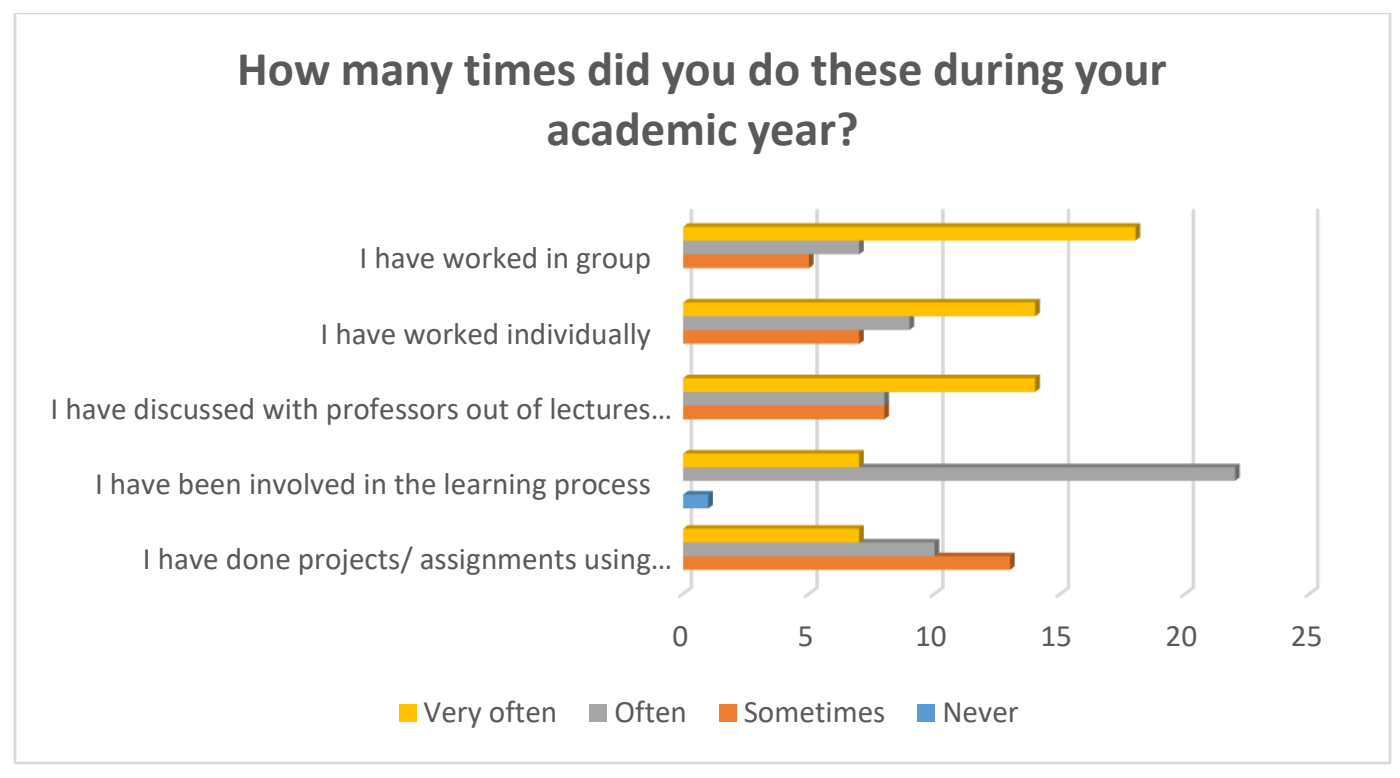

Fig. 8 - Student statistics in doing tasks/assignments

Engagement on the learning process depends from different methods professors introduce to students in order to develop their knowledge. Working in group and individually is a very common approach and students are familiar to it. However, students have different needs and they expect from professors to fulfill their lacks. Consultations with professors, use of technology and discussions during the lesson help students a lot and make them more interested in learning. The table above shows that there is a percentage of students who were never consulted to a professor and who used technology very little. 


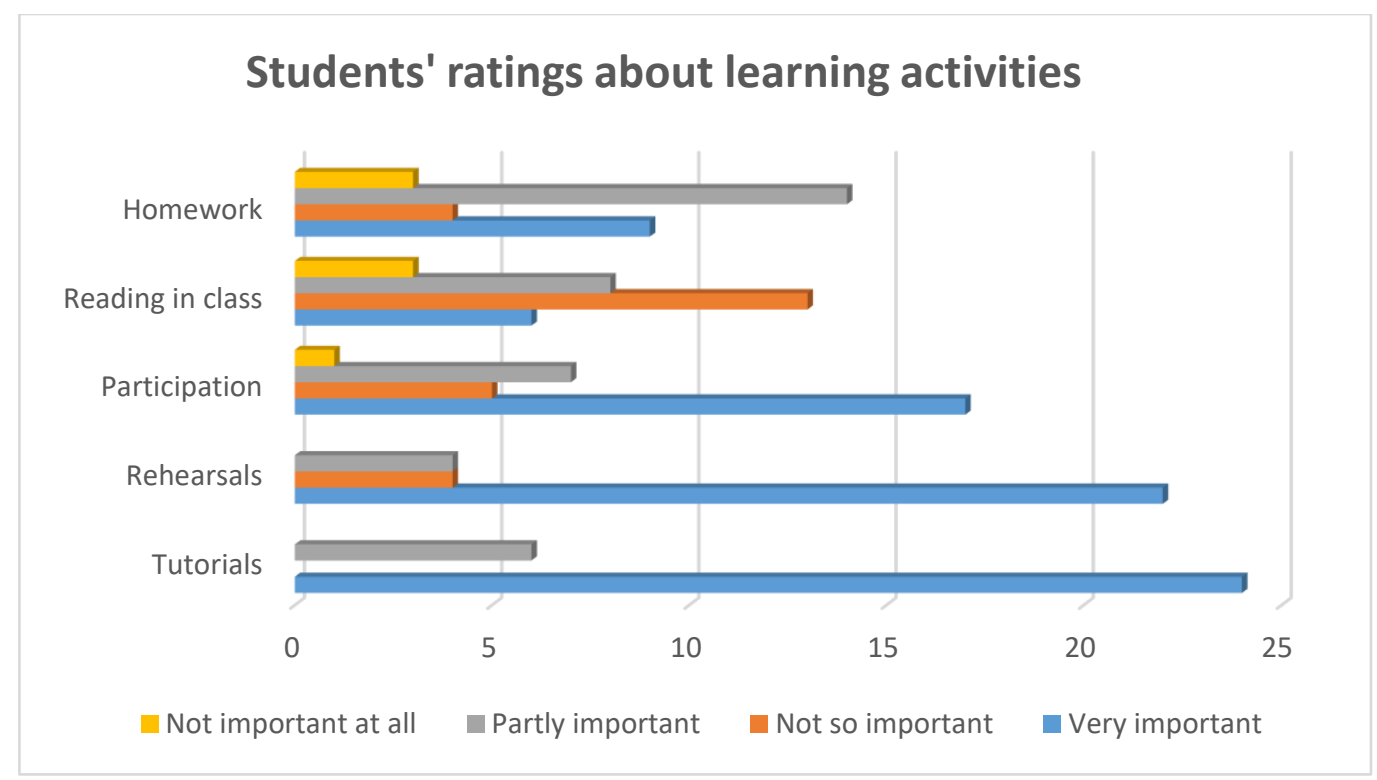

Fig. 9 - Considerations of students for different methods in learning

The last question was to investigate students' opinion in regard of what they assume to be important in the learning process, they point out that they view tutorials, participation and rehearsals as the most important features in advancing in learning, and the rest think that homework and reading in class is less important or not important at all. 


\subsection{DISCUSSION}

My thesis was focused on examining student engagement in the learning process, how they approach engagement in learning and what can influence in their advancement in both positive and negative sides. In this paper, it was highlighted the importance of engaging in the classroom with all its benefits.

This chapter serves to integrate the findings of the overall study. This is done with reference to the research question and methods employed. The remainder of this chapter is organized into three major subsections. The first section addresses to behavioral engagement - how students behave with their professors and peers. The second subsection provides commentary of the cognitive engagement level regarding the knowledge students have about engaging in the classroom and its benefits. The final subsection will address the third and final research question how students feel and percept engaging in the learning process.

As students consider important having good relationship with professors and colleagues, the study shows that this part may play a great role in making students active. When they have a sense of connection with each other, it helps students feel like they belong at the institution. Thus, students who hone their professional communication skills in a learning environment learn skills they need to succeed in their careers. Even though, professors tend to help and encourage students to learn and get involved in the lesson more, different thoughts and purposes make some students to think differently. There is a little percentage of students from the survey have negative attitude toward this. Students' perception about the class and the professor sometimes impacts in negative sides. For example, there are times when students do not feel accepted in the class and they feel kind of distracted from the professor (Marzano, 1992). However, sometimes it depends from students if they want to be engaged or not (Friedrick \& McColskey, 2012). Based on the other 
part of the research that was focused on students' perceptions for engagement, students revealed in some cases that they also play a great role in their advancement. Their responds discover that students dislike some activities that are in benefits of them, such as homework which they consider not so important and boring. There were times when students thought about skipping classes and avoiding hard tasks given by their professors and also they did not show a negative attitude toward reading activities in class. However, they consider participation as very important method to enhance in the learning process, tutorials and also rehearsals.

According to the cognitive level of engagement, students convey that not always they have the possibility to work projects by technology. They admit that technology helps them a lot in gaining good results and encouraging to learn, but the impossibility to use technology always makes them lazy and passive at several times. The last feature that was revealed through the survey was the issue of getting feedback from the tutor, no matter positive or negative one. A percentage of students confirmed that they have never discussed with professors out of lectures for the development in the learning process. Getting in touch with their tutors and gaining comments or feedback from them help students to have clear guidance and improve their learning, and through the study, students show filling their needs also influences in their educational achievement. 


\section{CHAPTER V}

\section{CONCLUSION}

A substantial, robust body of evidence exists to support assertions that individual student engagement in educationally purposive activities leads to more favorable educational outcomes.

The results of the study bear a relationship between student engagement and student achievement. From the perspective of the students the behavioral/participatory engagement contributes most to the achievement. However, students believe that emotional engagement, most specifically their relationship with their teacher and other students play the biggest role in their academic success in the setting. The evidence of cognitive engagement is unclear based on the study as the students identified this to a lesser degree in contributing to their success. Although this is the case, it is important to note that each student participant is considered academically strong. However, the idea of getting engaged in the learning process is also up to the students. The quality and quantity of effort a student put in school greatly influence the benefits of schooling. Learning will be better, and the probabilities of pursuing higher education or integrating the workforce with success will be higher. 


\section{References:}

Ballantine, J. (1997). The sociology of education: A systematic analysis. Upper Saddle River, NJ: Prentice Hall

Bernstein, B. (1977). Class and pedagogies: Visible and invisible. In J. Karabel \& A. Halsey (Eds.), Power and ideology in education (pp. 111-133). New York: Oxford Press

Erickson, F. (1987). Transformation and school success: The politics and culture of educational achievement. Anthropology and Education Quarterly. 18(4), 335-356.

Friedricks, J.A., \& McColskey (2012). The Measurement of Student Engagement: A Comparative Analysis of Various Methods and Student Self-report instruments. Handbook of Research on Student Engagement. 37. pp. 763-782.

Friedricks, J. A., \& Blumendfald, P.C., and Paris, A.H. (2004). School Engagement: Potential of the Concept, State of the Evidence. Review of Educational Research. 74 (1) pp. 59-109.

Irvin, J. L. \& Meitzer, J., and Dukes, M. S. (2007). Taking Action on Adolescent Literacy: Student Motivation, Engagement and Achievement. Carnegie Corporation, New York.

Libbey, H. P. (2004). Measuring Student Relationships to School: Attachment, Bonding, Connectedness, and Engagement. Journal of School Health. 74 (7). pp. 274-283. Retrieved from: http://www.jstor.org/stable/3516061?origin=JSTOR-

pdf\&seq=1\#page_scan_tab_contents

Mayes, C., \& Cutri, M. R., \& Rogers, C. P., and Montero, F. (2006). Understanding the whole student: Holistic multicultural education. Lanham, MD: Rowman \& Littlefield Education

Marzano, R. J. (1992). King of Classroom: Dimension 1: Positive attitudes and Perceptions about learning. Associate for Supervision and Curriculum Development. Alexandria, VA. Retrieved from: http://www.ascd.org/publications/books/61192107/chapters/Dimension-1@_ Positive-Attitudes-and-Perceptions-About-Learning.aspx

McLeod, S. A. (2008). Qualitative Quantitative. Retrieved from www.simplepsychology.org/qualitative-quantitative.html

Ogbu, J. (1982). Cultural discontinuities and schooling. Anthropology and Education Quarterly 13(4), 290-307

Ream, R. K. \& Rumberger, R. W. (2008). Student engagement, peer social capital, and school dropout among Mexican American and non-Latino White students. Sociology of Education. 81(April), 109-139.

Paratore, J. R., \& McCormack, R. L (n.d.). Peer talk in the classroom: Learning from research. Newark, DE: International Reading Association, pp. 130-155.

Brantlinger, E. (1993). Adolescents' interpretations of social class influences on schooling. Journal of Classroom Interaction. 28, pp. 1-12. 
Britton, J. (1987). A quiet form of research. In Goswami \& Peter R. (Eds). Reclaiming the classroom: Teacher research as an agency for change. Portsmouth, NH: Heinemann, pp. 13-19.

Heath, Sh. B. (1983). Ways with words: Language, life, and work in communities and classrooms. Cambridge University Press.

Kaser, S., \& Short, K. G. (1997). Exploring cultural diversity through peer talk. International Reading Association. pp. 45-65.

Smart, J (n.d.). Higher education. Handbook of theory and research. 1(1). pp. 1-64

Aitken, J. E., \& Neer, M. R. (1993). College student question-asking: The relationship of classroom communication apprehension and motivation. The Southern Communication Journal. 59, 73-79.

Allen, J. L., Long, K. M., O’Mara, J., \& Judd, B. B. (2008). Students' predispositions and orientations toward communication and perceptions of instructor reciprocity and learning. Communication Education. 57, 20-40.

Balas, A. (2000). Using participation to assess students' knowledge. College Teaching, 48, 122.

R. S. Anderson., \& B. W. Speck (n.d.). New directions for teaching and learning: Changing the way we grade student performance: Classroom assessment and the new learning paradigm. 74. pp. 33-40.

Oblinger, D., \& Oblinger, J. (n.d.). Educating the Net generation. Boulder. pp. 5.1-5.16. Retrieved December 2010, from http://www.educause.edu/educatingthenetgen

Willms, J. D. (2003). Student Engagement at School: A Sense of Belonging and Participation. Results from PISA 2000. Paris: Organization for Economic Co-operation and Development (OECD). Retrieved from http://www.unb.ca/crisp/pdf/0306.pdf

Friesen, S. (2008). Effective teaching practices - A framework. Toronto: Canadian Education Association.

Hargreaves, D. H. (2004). Learning for Life: the Foundations for Lifelong Learning. Bristol:

Policy Press. 


\section{Appendix}

1. Kur më duhet të ndjek ligjërata ndihem...(Përgjigju vetëm me tik)

I lumtur $\square$ Jo aq i lumtur $\square$ I palumtur $\square$

2. Sa është e rëndësishme të keni lidhje të mira me profesorëet dhe kolegët ...

Gjithmonë $\square$ Disaherë $\square$ Shpesh $\square$ Kurrë $\square$

3. Kur kam detyra të shtëpisë unë ndihem...

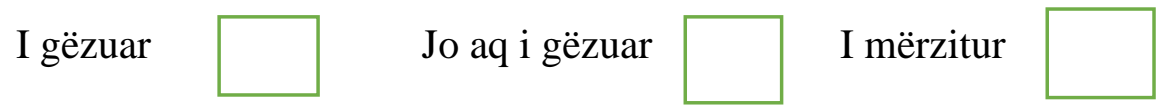

4. Shumica e profesorëve të mi kujdesen se si po zhvillohem në mësim (Bëj me tik një nga përgjigjet)

Kujdesen mjaft shumë

Nuk kujdesen fare

Tregojnë pak interes

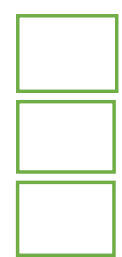

5. Sa të rëndësishëm e konsideroni përdorimin e teknologjisë në mësim?

Shumë të rëndësishëm

Deri diku të rëndësishëm

Jo aq të rëndësishëm

Të parëndësishëm

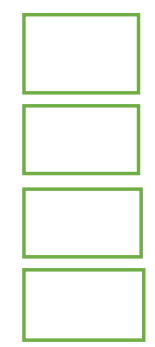


6. A mendoni se gjërat që jeni duke mësuar po ju ndihmojnë në plotësimin e nevojave tuaja për shkollim?

Plotësisht pajtohem

Deri diku po

Jo edhe aq

Mendoj se jo

Ide tjetër

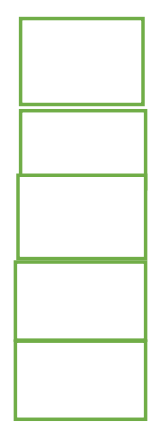

7. Ju ka shkuar ndonjëherë në mendje të lini orët/ligjëratat?
Asnjëherë
Disaherë
Rrallëherë
Shpeshherë
Gjithmonë

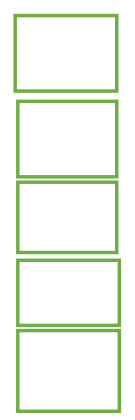

8. Gjatë vitit tuaj akademik sa herë keni bërë këto gjëra?

Vlerësoni në bazë të listës me numra

1- Shumë shpesh

2-Shpesh

3- Disaherë

4- Kurrë

Kam punuar në projekte në grup

Kam punuar në projekte individuale

Kam diskutuar me profesorë rreth mësimeve jashtë ligjëratave

Jam përfshirë ose kam marrë pjesë gjatë
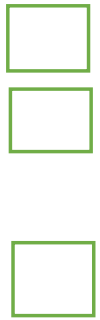
zhvillimit të mësimit

Kam bërë punime duke përdorur teknologjinë

9. Sa i konsideroni të rëndësishme këto aktivitete?

Vlerësoni nga 1-4

1-Shumë rëndësishme

2-Deri diku të rëndësishme

3-Jo edhe aq të rëndësishme

4-Të parëndësishme

Detyrat e shtëpisë

Leximi në klasë

Participimi gjatë mësimit

Përgatitjet ose provat para prezantimit

Ushtrimet

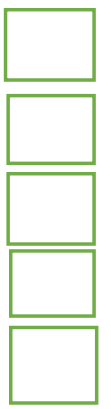

